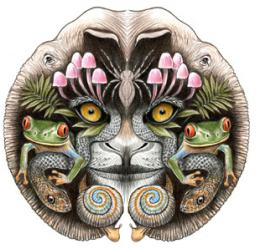

SSN 0974-7907 (Online) ISSN 0974-7893 (Print)

\section{OPEN ACCESS}

\title{
BAUHinia PHOENICEA B. Heyne ex Wight \& ARN., the LESS KNOWN ENDEMIC AND THREATENED LIANA OF THE SOUTHERN WESTERN GHATS, REQUIRES IMMEDIATE CONSERVATION
}

\author{
R.K. Singh ${ }^{1}$, P. G. Diwakar ${ }^{2}$ \& J.V. Sudhakar ${ }^{3}$
}

${ }^{1}$ Botanical Survey of India, Central Regional Centre, 10-Chatham Lines, Allahabad, Uttar Pradesh 211002, India ${ }^{2}$ Botanical Survey of India, Western Regional Centre, 7-Koregaon Road, Pune, Maharashtra 411001, India ${ }^{3}$ Botanical Survey of India, Southern Regional Centre, TNAU Campus, Lawley Road, Coimbatore 641003, India

${ }^{1}$ rksbsiadsingh@yahoo.co.in (corresponding author), 2. pgdiwakar1951@gmail.com, ${ }^{3}$ jvsbsi@yahoo.com

Abstract: Bauhinia phoenicea is endemic to the Western Ghats of Karnataka, Kerala and Tamil Nadu. It is assessed as Vulnerable as per the IUCN red list criteria using primary and secondary information on trends in EOO, AOO and sub-populations. Taxonomy of the species, distribution, variability in the number of fertile stamens, and causes of rarity are discussed. Lectotypification is also made for $B$. benthamii, a taxonomic synonym of $B$. phoenicea.

Keywords: Bauhinia benthamii, B. phoenicea, IUCN Red List Assessment, Karnataka, Kerala, southern Western Ghats, Tamil Nadu, Vulnerable.

The genus Bauhinia L. is represented by ca. 300 species (Wunderlin et al. 1987). In India, the genus is represented by 18 species, one subspecies and one variety in wild and 10 cultivated ornamental species. Of the wild species, two are endemic to India: one tree species, Bauhinia foveolata Dalzell to Dadra \& Nagar Haveli, Gujarat, Karnataka and Maharashtra; one liana,
B. phoenicea B. Heyne ex Wight \& Arn. to the Western Ghats of Karnataka, Kerala and Tamil Nadu (Baker 1878; Gamble 1919; Sharma et al. 1984; Sanjappa 1992; Bandyopadhyay 2001 \& 2012; Bandyopadhyay et al. 2006).

Of all the species of Bauhinia, B. phoenicea is exceptionally beautiful with brick-red flowers occurring on the slopes of the ghat area in small fragmented patches in evergreen and semi-evergreen forests. During the British period the species was gregariously spread throughout the evergreen forests of the southern Western Ghats, to such an extent that it covered the major tree canopy of the forests. The species thus became a matter of serious concern in 1919 when J.S. Gamble commented 'it is very destructive to forest trees and has to be cut'. Since then the population status of this species has not been known. During
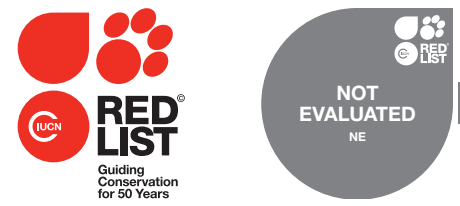

Bauhinia phoenicea
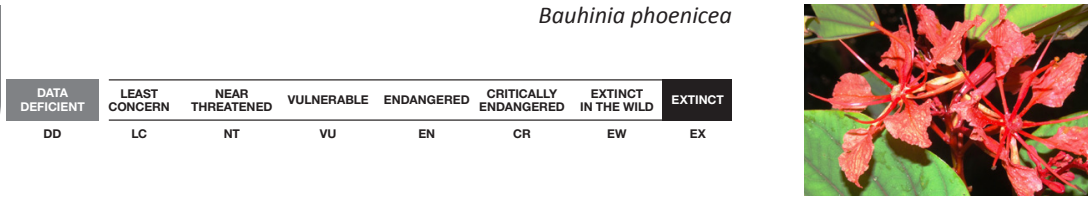

DOI: http://dx.doi.org/10.11609/JoTT.o3825.7676-82

Editor: B. Ravi Prasad Rao, Sri Krishnadevaraya University, Anantapuramu, India.

Date of publication: 26 August 2015 (online \& print)

Manuscript details: Ms \# 03825 | Received 28 October 2013 | Final received 30 July 2015 | Finally accepted 02 August 2015

Citation: Singh, R.K., P.G. Diwakar \& J.V. Sudhakar (2015). Bauhinia phoenicea B. Heyne ex Wight \& Arn., the less known endemic and threatened liana of the southern Western Ghats, requires immediate conservation. Journal of Threatened Taxa 7(10): 7676-7682; http://dx.doi.org/10.11609/JoTT.o3825.7676-82

Copyright: (C Singh et al. 2015. Creative Commons Attribution 4.0 International License. JoTT allows unrestricted use of this article in any medium, reproduction and distribution by providing adequate credit to the authors and the source of publication.

Funding: Botanical Survey of India.

Competing interests: The authors declare no competing interests.

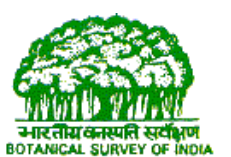

Acknowledgements: The authors are highly thankful to Prof. James L. Reveal, Cornell University, Ithaca, New York, U.S.A. for his critical comments and suggestions on the manuscript. We are also thankful to Dr. P. Singh, Director, Botanical Survey of India, Kolkata and to the Head of Office, Botanical Survey of India, Central Regional Centre, Allahabad for facilities. The generous support rendered by the Forest officials of Karnataka, Kerala and Tamil Nadu during field explorations is duly acknowledged. 
our surveys from 2007 to 2012 in the Western Ghats region covering Karnataka, Kerala and Tamil Nadu, the once expansive $B$. phoenicea had drastically collapsed to small populations of not more than 35-60 mature individuals in small fragmented patches in Dakshina Kannada, Hassan, Kodagu, Mysore, Shimoga and Udupi districts of Karnataka; Idukki, Kannur, Kollam, Kottayam, Palakkad, Pathanamthitta and Thiruvananthapuram of Kerala; Coimbatore and Nilgiris of Tamil Nadu. Further the populations were confined to the peripheral slopes of the ghat area and hence are being constantly exposed to developmental activities, mainly road construction and expansion.

The drastic population decline paves the way to a realization that probably the plants were razed off subsequent to J.S. Gamble's concern (1919) and also because this liana was not found to have any economic value, despite of its ornamental significance. Its seed viability was also found to be negligible both in the wild and under controlled conditions as there were hardly one or two juvenile plantlets noticed in the natural habitat, while none were found to germinate ex situ (Experimental garden, BSI, Pune). The seedlings in the natural habitat also failed to survive possibly due to a dearth of sunlight under the dense canopy. Further the majority of seeds get washed off by rain waters into flowing rivulets joining the rivers and are carried off to distant uncongenial locations.

The once gregariously spread species has dwindled to mere scanty patches in about one century. Its current extent of occurrence is less than $3000 \mathrm{~km}^{2}$ and the area of occupancy less than $750 \mathrm{~km}^{2}$ in 15 districts of the southern Western Ghats, with a total population comprising less than 900 mature individuals. Hence the species conservation status has now been identified as
'Vulnerable' based on IUCN 2012. We, therefore, call upon the attention of conservation biologists towards the dwindling population of this highly ornamental species before its status diminishes further. Additionally, the economic potential of this species has never been reported earlier and this opens a vista for future research.

\section{Bauhinia phoenicea B. Heyne ex Wight \& Arn., (Images 1-6)}

Prodr. Fl. Ind. Orient. 1: 296. 1834; Baker in Hook. f., Fl. Brit. India 2: 283. 1878; Gamble, Fl. Madras 407. 1919; Sanjappa, Legumes Ind. 4. 1991; Bandyopadhyay et al. in J. Econ. Taxon. Bot. 29: 776, f. 10 (a-h). 2005 (2006). Phanera phoenicea (B. Heyne ex Wight \& Arn.) Benth. in Miq., PI. Jungh. 262. 1852. Perlebia phoenicea (B. Heyne ex Wight \& Arn.) A. Schmitz in Bull. Soc. Roy. Bot. Belgique 110(1-2): 15. 1977.

Lectotype: India, 29.xii.1816, B. Heyne s.n. in Wallich Numer. List no. 5800, K (K-001122196!), designated by Bandyopadhyay 2012.

Residual syntype: India, s.d., B. Heyne s.n. in Wallich Numer. List no. 5800, K (K-000760778!).

Bauhinia benthamii Bedd., Icon. PI. Ind. Or. 22, t. 107. 1874.

Lectotype (designated here): India, Kerala, Wynad (now Wayanad), from the foot of the ghats up to 2000 ft., Jan 1868, R.H. Beddome s.n., K (K-000760776!) (Image 8).

Residual syntype: India, Karnataka, South Canara, 1866, R. H. Beddome s.n., MH (Acc. no. 18395) (Image 9).

Local name: Kannada 'Kempuyatha Balli'; Tamil 'Thukarakkali'; English 'Crimson Mountain Ebony'.

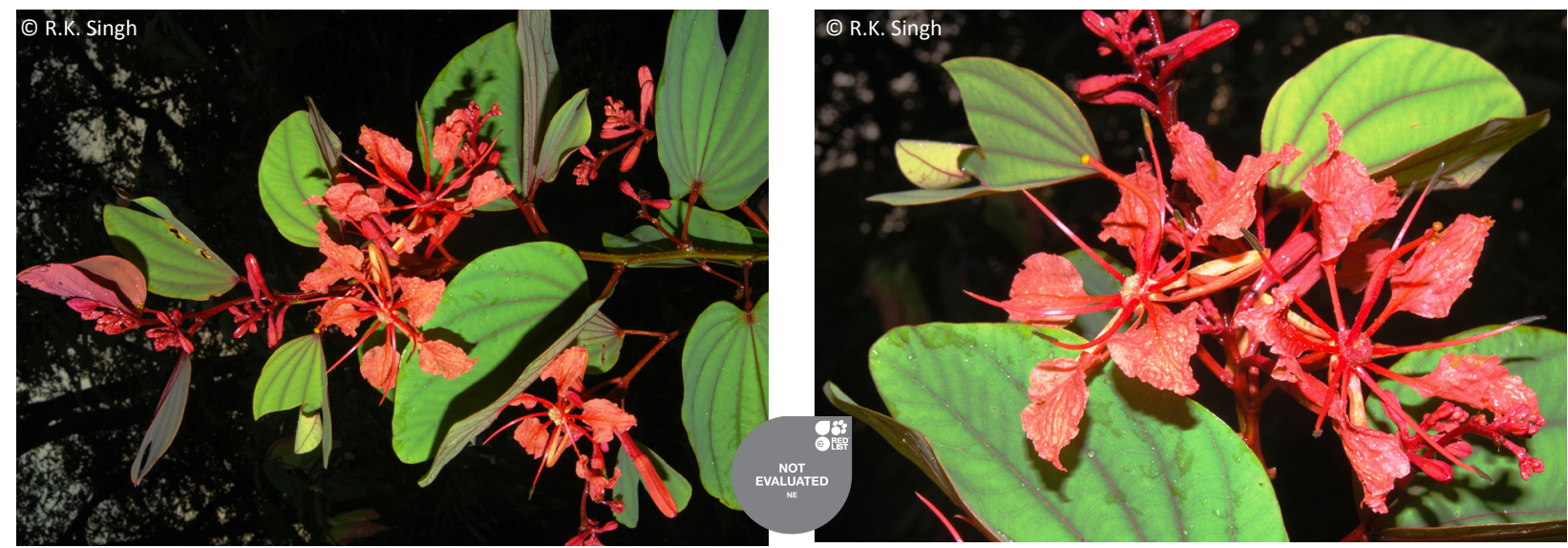

Images 1-2. Bauhinia phoenicea B. Heyne ex Wight \& Arn. 
Lianas or scandent shrubs, without tendrils, to $10 \mathrm{~m}$ high; branchlets ferruginous pubescent. Leaves 5-15 x 3-12 cm, ovate-suborbicular, alternate, simple, bifid to $1 / 6-1 / 3$ of their length, palmately ribbed, obtuse or subacute at apex, shallowly cordate or obtuse at base, 7-11-nerved, coriaceous, sparsely silky on ribs when young, glabrous later; petioles $0.7-4.2 \mathrm{~cm}$ long, glabrous; stipules $0.1-0.15 \mathrm{~cm}$ long, ovate, glabrous. Flowers in axillary and terminal corymbs, 7-14 cm long, 5-8.5 cm wide, brick reddish, showy, zygomorphic; bracts and bracteoles ovate, caducous; pedicels $0.7-1.6 \mathrm{~cm}$ long, ferruginous pubescent. Calyx 5-lobed, spathaceous, imbricate, yellowish-red; lobes free or connate at apex. Petals 5, 2-4 x 0.5-1.6 cm, oblanceolate-ovate, imbricate, glabrous; claws $0.7-1.8 \mathrm{~cm}$ long, glabrous. Stamens 10; fertile stamens $3-5$, rarely 2 ; sterile filaments without anthers other than the staminodes $1-3$ or 0; filaments $2.5-4.2 \mathrm{~cm}$ long, glabrous, red; anthers $0.6-0.8 \mathrm{~cm}$ long; staminodes 5, minute, obscure. Gynophore 0.7-1.4 $\mathrm{cm}$ long, ferruginous tomentose; ovary 6-10 x 1.5-2.5 $\mathrm{mm}$, ferruginous tomentose; style $1.5-2.2 \mathrm{~cm}$ long, red, ferruginous tomentose; stigma $\pm 0.5 \mathrm{~cm}$ across, capitate, yellow with a reddish tinge. Pods $14-18 \times 3-6 \mathrm{~cm}$, oblanceolate-oblong, woody, ferruginous tomentose, stalked, flattened, beaked at apex, ridged along upper suture, 4-7-seeded. Seeds $1.4-1.9 \times 1.2-1.5 \mathrm{~cm}$, ovatesuborbicular, compressed, albuminous, dark brown.

Specimens examined: 62664, 18.v.1960, Someshwar Ghat, Agumbe, Mysore, Karnataka, coll. R.S. Raghavan; 67907, 29.x.1960, Someshwar Ghat, Agumbe, Mysore, Karnataka, coll. R.S. Raghavan; 69374, 06.ii.1961, Someshwar Ghat, Agumbe, Mysore, Karnataka, coll. R.S. Raghavan; 86393, 13.x.1962, Someshwar Ghat, Agumbe, Mysore, Karnataka, coll. R.S. Raghavan; 86393, 20.ii.1963, Someshwar Ghat, Agumbe, Mysore, Karnataka, coll. R.S. Raghavan; 180423 A \& B, 22.xi.1998, Shiradi Ghat, S. Kanara, Karnataka, coll. M.J. Kothari; 184016, 22.xii.2007, Chittur forest, Mookambika Wildlife Sanctuary, Udupi District, Karnataka, coll. R.Kr. Singh \& Diwakar; 193221, 24.xi.2009, Kollur forest, Mookambika Wildlife Sanctuary, Udupi District, Karnataka, coll. R.Kr. Singh \& Diwakar; 3021, 04.xii.2010, Agumbe Ghat forest, Shimoga District, Karnataka, coll. R.Kr. Singh; 3085, 15.xii.2010, Shiradi Ghat forest, Dakshina Kannda, Karnataka, coll. R.Kr. Singh; 185286, 21.xi.2011, Mukkunnimala forest, Neyyattinkara Taluk, Thiruvananthapuram District, Kerala, coll. R.Kr. Singh; 185298, 03.xii.2011, Silent Valley forest, Palakkad District, Kerala, coll. R.Kr. Singh; 185368, 12.xii.2011, Nilgiris District, Tamil Nadu, coll. R.Kr. Singh - (all in BSI). 2364, 14.xi.1900, South Canara, Karnataka, coll. C.A.

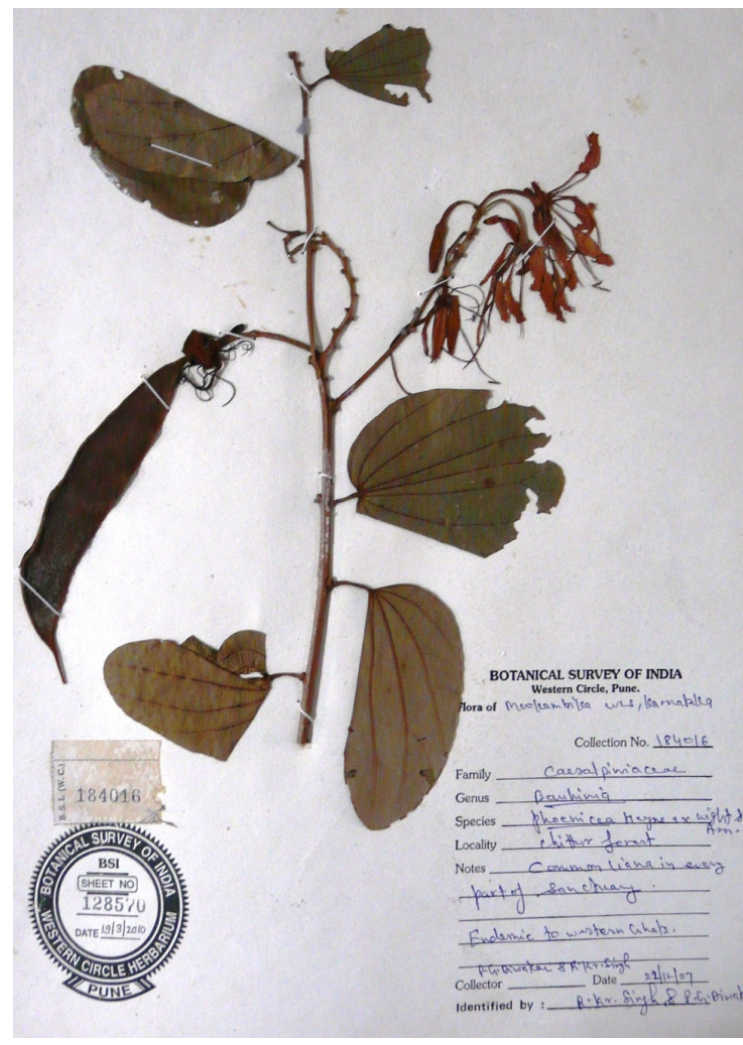

Image 3. Herbarium of Bauhinia phoenicea.

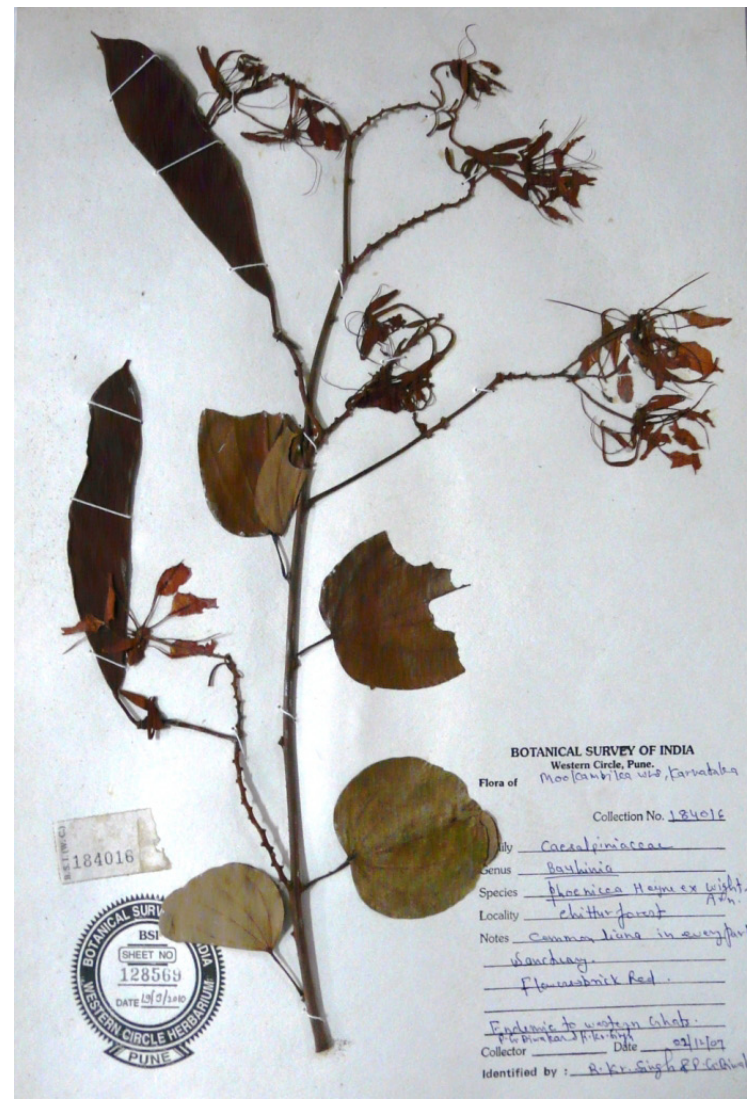

Image 4. Herbarium of Bauhinia phoenicea. 


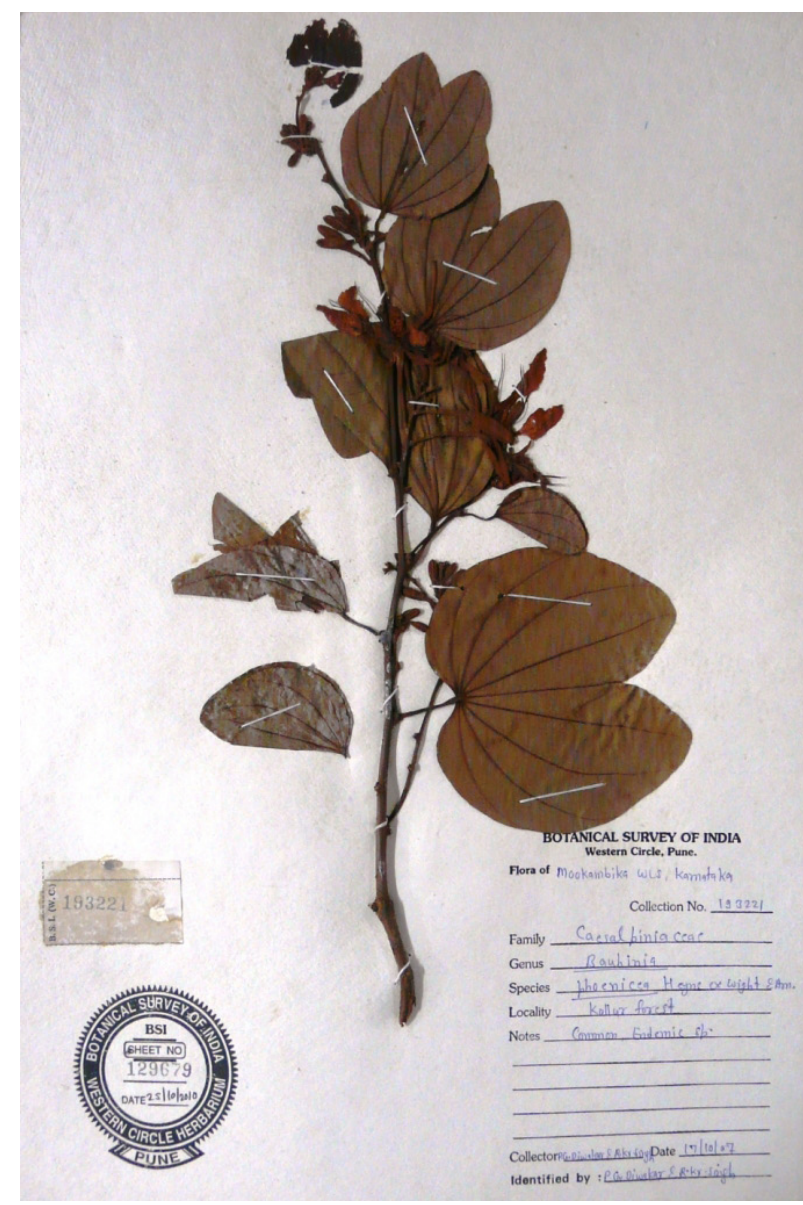

Image 5. Herbarium of Bauhinia phoenicea.

Barber; 6297, 27.xii.1938, South Canara, Karnataka, coll. S.R. Raju; 72316, 4.xi.1981, Coorg District, coll. S.R. Srinivasan; 49209, 26.xi.1976, Quilon District, Kerala, coll. M. Chandrabose; 54318, 21.iii.1978, Quilon District, Kerala, coll. C.N. Mohanan; 33300, 23.xii.1969, Palghat District, Kerala, coll. E. Vajravelu; 89358, 21.x.1989, Pathanamthitta District, Kerala, coll. R. Chandrasekaran; 42459, 10.x.1972, Idukki District, Kerala, coll. B.D. Sharma; 74786, 24.ix.1992, Idukki District, Kerala, coll. K. Ramamurthy; 90016, 19.xii.1986, Idukki District, Kerala, coll. P. Bhargavan; 58228, 5.xi.1978, Cannanore District, Kerala, coll. V.S. Ramachandran; 29512, 6.xii.1967, Cannanore District, Kerala, coll. J.L. Ellis; 1004, 19.xi.1984, Kottayam District, Kerala, coll. V.T. Antony; 5934, 19.v.1903, Udumanparai, Anamalais, Tamil Nadu, coll. C.A. Barber - (all in $\mathrm{MH}$ ).

Flowering and Fruiting: October-May.

Illustration: Bedd., I.c.; Bandyopadhyay et al., I.c.

Distribution: Endemic to Karnataka (Dakshina Kannada, Hassan, Kodagu, Mysore, Shimoga and Udupi), Kerala (Idukki, Kannur, Kollam, Kottayam, Palakkad, Pathanamthitta and Thiruvananthapuram), and Tamil

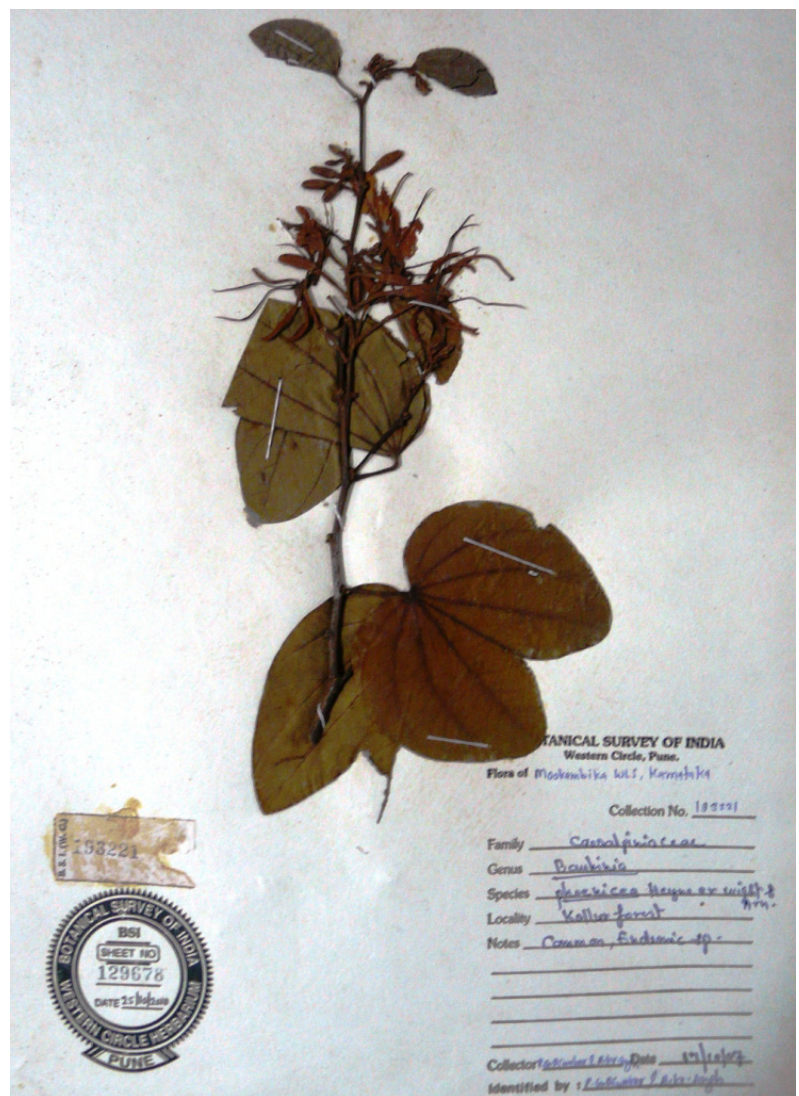

Image 6. Herbarium of Bauhinia phoenicea.

Nadu (Coimbatore and Nilgiris).

Habitat: Grows on the slopes of the ghat area in semi-evergreen and evergreen forests at 150-1800 m altitude.

Notes: The range of species occurrence is reported from Agumbe Ghat, Shimoga District, Karnataka up to Thiruvananthapuram District of Kerala. Its distribution in Maharashtra State, as given by Sanjappa 1992, is doubtful as Bandyopadhyay et al. 2006 in his revisionary work has stated species distribution only in Karnataka, Kerala and Tamil Nadu and during the present study we could not find any collection of the specimens from Maharashtra in any of the Indian herbaria. Further none of the live populations could be traced from Maharashtra during our extensive field surveys.

Our field studies of flowering specimens of $B$. phoenicea in a range of populations of the southern Western Ghats regions of Karnataka, Kerala and Tamil Nadu show that the number of anther bearing fertile stamens vary from three to five, rarely two, with a corresponding number of sterile filaments (filaments without anthers other than the 5 minute staminodes) up to three, all in the same plant. A study of the herbarium specimens also revealed the same stamen condition. 


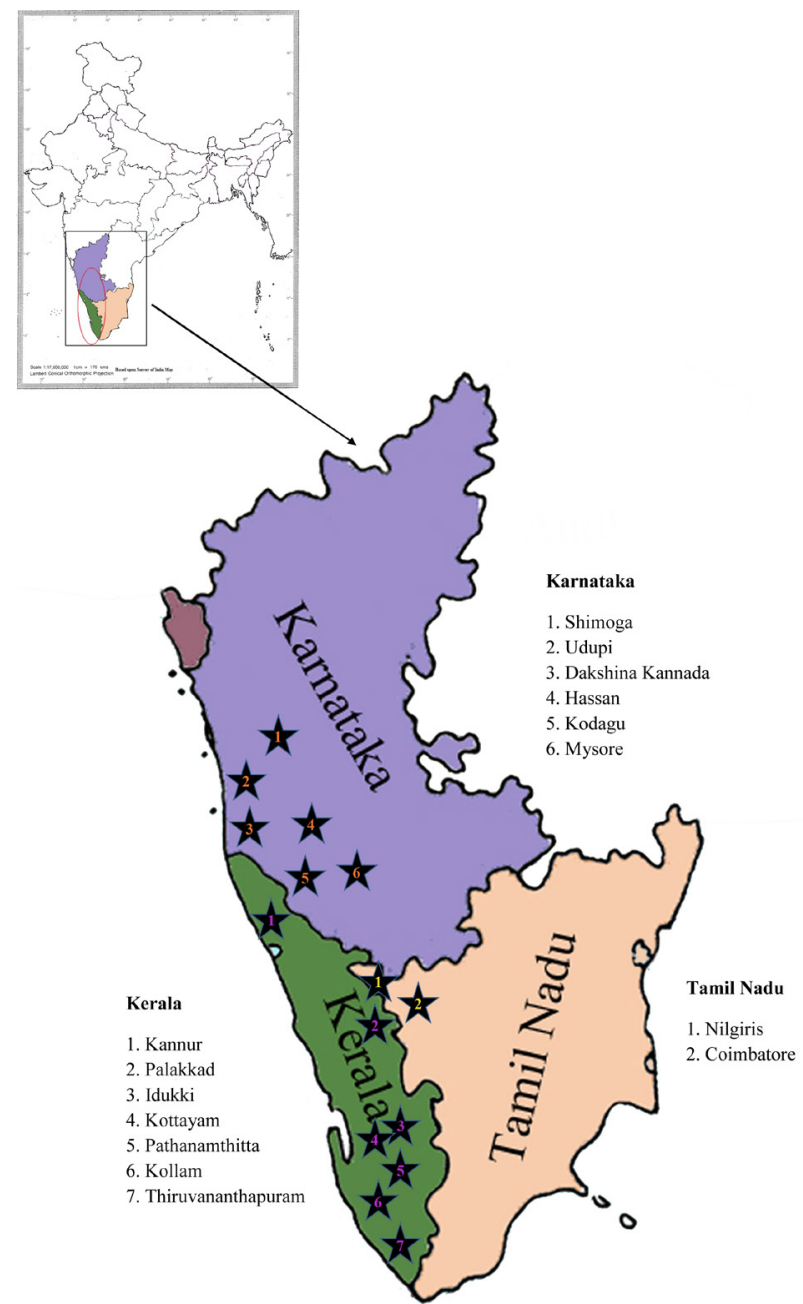

Image 7. Distribution of Bauhinia phoenicea.

Beddome described $B$. benthamii on the basis of a specimen from 'A most gorgeous creeper, very common about the Wynad and South Canara ghats, from the foot up to 1,500 or 2,000 feet elevation; it climbs to the top of the highest trees', but no specific herbarium sheet was designated as the holotype. Pertaining to this specification, only two specimens collected by Beddome are now extant, one each at $\mathrm{K}$ and $\mathrm{MH}$. The best one, $\mathrm{K}-000760776$, is designated here as the lectotype as it agrees well with the protologue.

IUCN threat status: Based on the literature, assessment and field observations from 2007 to 2012, Bauhinia phoenicea is currently categorized as Vulnerable [B1B2b(i,ii,iii,v) c(i,ii,iv); C2a(i); D1] (Appendix 1).

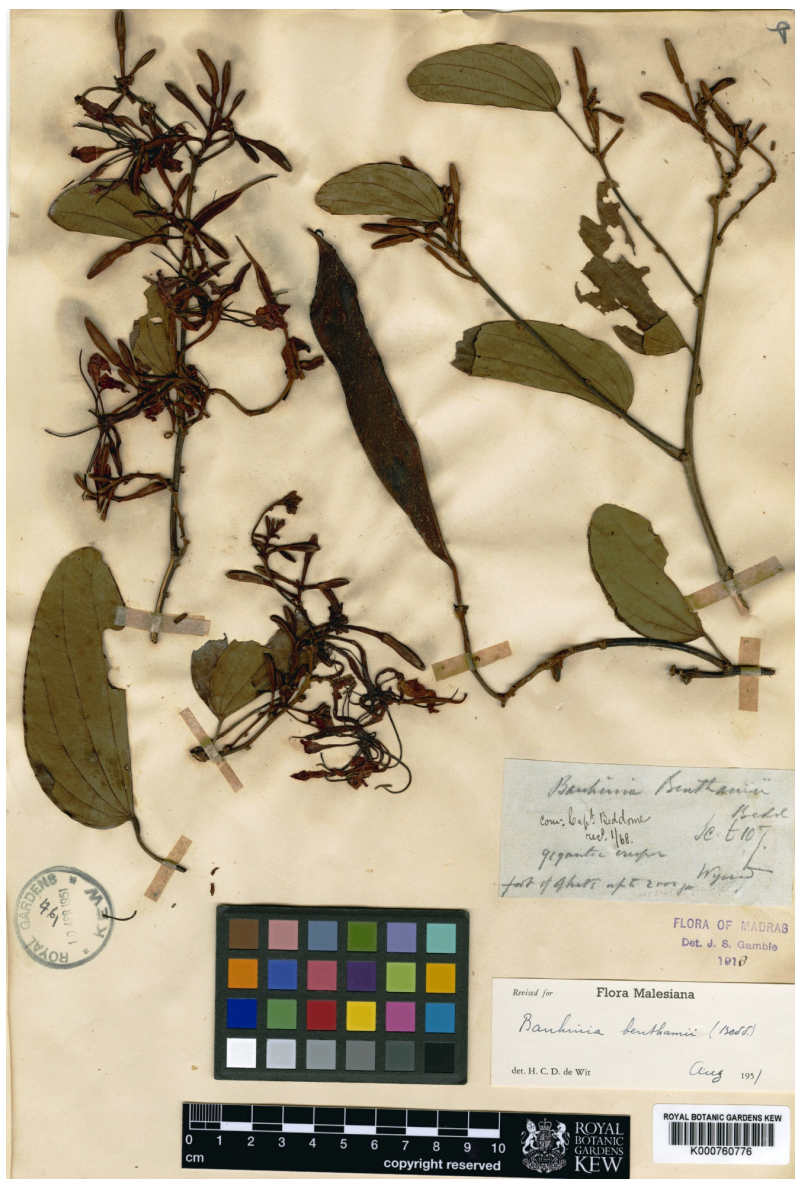

Image 8. Lectotype of Bauhinia benthamii (K-000760776, (c) the Board of Trustees of the Royal Botanic Gardens, Kew).

\section{REFERENCES}

Baker, J.G. (1878). Bauhinia Linn., pp. 275-285. In: Hooker, J.D. (ed.). Flora of British India - Vol. 2. L. Reeve \& Co., London.

Bandyopadhyay, S. (2001). Miscellaneous notes on Bauhinia L. (Leguminosae: Caesalpinioideae) - II. Journal of Economic and Taxonomic Botany 25(1): 10-12.

Bandyopadhyay, S. (2012). Lectotypification of Bauhinia phoenicea Wight \& Arn. (Leguminosae: Caesalpinioideae). Candollea 67(1): 41-43.

Bandyopadhyay, S., K. Thothathri \& B.D. Sharma (2006). The genus Bauhinia L. (Leguminosae: Caesalpinioideae) in India. Journal of Economic and Taxonomic Botany 29(4): 763-801.

Gamble, J.S. (1919). Flora of the Presidency of Madras. Adlard and Son Ltd., London, 407-408pp.

IUCN (2012). IUCN Red List Categories and Criteria: Version 3.1. Second edition. International Union for Conservation of Nature and Natural Resources, Gland and Cambridge.

Sanjappa, M. (1992). Legumes of India. Bishen Singh Mahendra Pal Singh, Dehra Dun, 2-8pp.

Sharma, B.D., N.P. Singh, R.S. Raghavan \& U.R. Deshpande (1984). Flora of Karnataka Analysis. Botanical Survey of India, Howrah, 87-91pp.

Wunderlin, R., K. Larsen \& S.S. Larsen (1987). Reorganization of the Cercideae (Fabaceae: Caesalpinioideae). Danske Biologiske Skrifter 28: $1-40$. 


\section{APPENDIX 1. RED LIST ASSESSMENT: BAUHINIA PHOENICEA}

Kingdom: Plantae

Phylum: Tracheophyta

Class: Magnoliopsida

Order: Fabales

Family: Fabaceae

Genus: Bauhinia

Species: phoenicea

Authority: Wight \& Arnott, 1834

Common name: Crimson Mountain Ebony (English); Kempuyatha Balli (Kannada); Thukarakkali (Tamil).

Taxonomic notes: The species was described by Wight \& Arnott (1834) on the basis of specimens of B. heyne s.n. in Wallich Numer. List no. 5800 from India. The species is considered valid and Bauhinia phoenicea is an accepted name as per version 1.1 of The Plant List (2013).

\section{ASSESSMENT INFORMATION}

Red List Category and Criteria (Version 3.1): Vulnerable [B2ab(i,ii,iii,iv,v); C2a(i); D1].

Justification: Bauhinia phoenicea is assessed as Vulnerable as its current area of occupancy is estimated to be less than $750 \mathrm{~km}^{2}$ in 15 districts of the southern Western Ghats, restricted to the western slopes of the Western Ghats and with a total population comprising less than 900 mature individuals. As it has been perceived as being very destructive to forest trees it has been cut by forest authorities and local dwellers and these scandent shrubs are replaced with plantations Acacia spp., Areca catechu, Cocos nucifera, Hevea brasiliensis and Tectona grandis. Seed viability of this species is found to be less. Owing to these, there is a continuing decline observed in the area/extent and quality of habitat, and continuing decline inferred in the number of locations/subpopulations and in the number of mature individuals. The species is also threatened as being constantly exposed to development activities in the forests, mainly road construction, expansion, removing of plants for making cattle trenches and erection of temporary huts by local tribes.

\section{GEOgRAPHIC RANGE / DISTRIBUTION INFORMATION}

Range description: The species is restricted in its distribution in central and southern Western Ghats from Shimoga District of Karnataka in the north to Thiruvananthapuram District of Kerala in the south.

Countries of occurrence: Native to India (Karnataka, Kerala and Tamil Nadu).

Extent of Occurrence (EOO): EOO is estimated to be less than less than $40,000 \mathrm{~km}^{2}$ considering its occurrence on the slopes of the Western Ghats of Karnataka, Kerala and Tamil Nadu as small fragmented populations in evergreen or semi-evergreen forests.

Area of Occupancy (AOO): AOO is estimated to be less than $750 \mathrm{~km}^{2}$ considering the extant of fragmented populations in 15 districts of three states of the Western Ghats, i.e. Karnataka (c. $375 \mathrm{~km}^{2}$ ), Kerala (c. $325 \mathrm{~km}^{2}$ ) and Tamil Nadu (c. $38 \mathrm{~km}^{2}$ ).

Number of locations: The species is currently restricted to a few severely fragmented locations in Dakshina Kannada, Hassan, Kodagu, Mysuru, Shivamogge and Udupi districts of Karnataka; Idukki, Kannur, Kollam, Kottayam, Palakkad, Pathanamthitta and Thiruvananthapuram of Kerala; Coimbatore and Nilgiris of Tamil Nadu.

Range map: See Image 7.

\section{POPULATION INFORMATION}

Population: The species is estimated to have less than 900 mature individuals, of which about 550 individuals are restricted to Karnataka.

Population trend: The population of this species is dwindling. Based on the perusal of the literature, herbaria information, and observations in the field the population of this species has dwindled by more than $75 \%$ in the last 100 years due to various threats discussed above.

\section{HABITAT AND ECOLOGICAL INFORMATION}

Habitat and ecology: It is a scandent shrubs or liana without tendrils, to $10 \mathrm{~m}$ high, grows on the peripheral slopes of the ghat area in semi-evergreen and evergreen forests of Western Ghats, sometimes found in interior of forests. It grows between 150 to $1800 \mathrm{~m}$ altitude ranges. Vegetative growth occurs throughout the year with flowering starts in October and continues until December. Flower blooms seen in between October to November. Fruiting starts in December and continues until May. At times both flowering and fruiting can be observed in the month of December. Mature fruits are seen during March to April and seed dispersal during May to June. The associated vegetation of this species are Alseodaphne semecarpifolia, Bischofia javanica, Cinnamomum sulphuratum, Flacourtia montana, Hopea ponga, Hydnocarpus pentandra, Ixora brachiata, Ligustrum perrotettii, Litsea coriacea, Macaranga peltata, Mallotus ferrugineus, Meyna laxiflora, Olea dioica, Pittosporum dasycaulon, Polyalthia fragrans, Uvaria narum and Wendlandia thyrsoidea.

System: Terrestrial scandent shrub or liana. 


\section{INFORMATION ON THREATS}

Threats: The main threats to the remaining fragmented populations in Western Ghats in 15 districts of three states are from human development activities mainly road construction and expansion, and making of cattle trenches along peripheral regions of forests. Additional threats: Local people replace this species with plantation of other economical species and erection of temporary huts due to lack of awareness.

\section{USE AND TRADE INFORMATION}

Use: No use reported for this species so far.

Livelihoods and sustenance: The people are not dependent on this species for their livelihood or sustenance.

Trend in off take from the wild: Not reported so far. This species can be used for ornamental purposes but it is not cultivated till now anywhere.

Trend in off take from cultivation: Not reported so far.

\section{INFORMATION ON CONSERVATION ACTIONS}

Conservation actions: The species is not yet in any organized conservation programme. The site of remaining fragmented populations in 15 districts of three states of the Western Ghats comes mainly in reserve forest area, but these areas do not imply special attention on conservation of the species. Local communities and competent authorities are being mobilized for conservation. There is an immediate need of conservation action to protect the species from human activities as well as habitat protection.

Research in place: There is no systematic research in place other than frequent surveys.

Research needed: Systematic surveys, proper monitoring, effects of threats on populations, micro-propagation studies, seed viability experiments and ex situ conservation methods are needed.

Monitoring in place: There is no monitoring on population or habitat of this species in place so far.

Monitoring needed: Population and habitat monitoring is essential and must be implemented as early as possible.

Education in place: No record on formal or informal education about this species in place.

Education needed: Awareness programmes about the biological significance of this species to local people and forest department are essential.

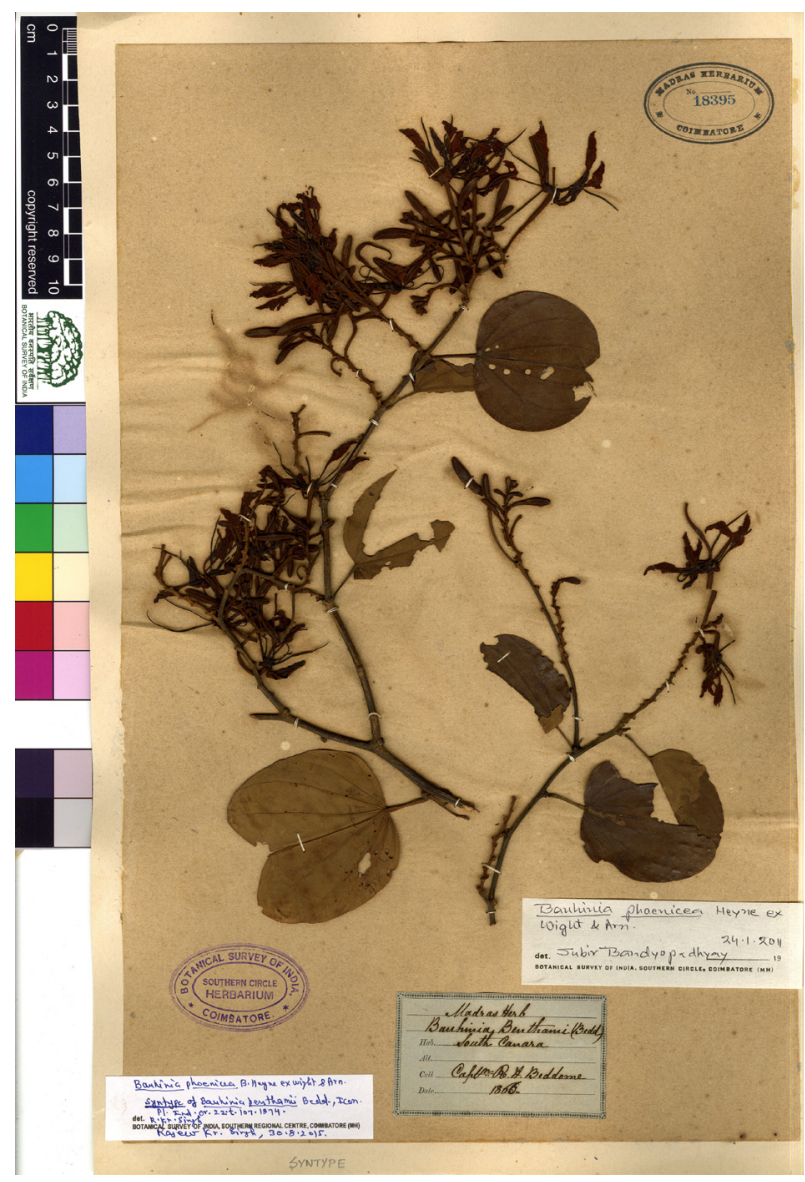

Image 9. Syntype of Bauhinia benthamii (Acc. no. 18395, (C) Botanical Survey of India, SRC, Coimbatore). 